\title{
Youth Suicide Research: Some Current Challenges and Opportunities
}

\author{
By Jo Robinson and Zoe Teh
}

\section{ABSTRACT}

Rates of youth suicide are increasing. Frameworks for suicide prevention activities exist and span universal, selective and indicated interventions, but how do they apply to young people? In order to answer this question, we conducted i) a systematic review and meta-analysis of almost 100 studies that examined the full spectrum of youth suicide interventions, and ii) a consultation with young people from across Australia. These activities led to a program of work that was specifically developed by and for young people and that has young people as active partners in the research. In this paper we describe some of the gaps in current youth suicide prevention research efforts and discuss some of the challenges and opportunities that including young people as active partners in suicide research presents.

\section{SAMMENDRAG}

Selvmordsraten blant unge øker. Det eksisterer rammeverk for selvmordsforebyggende tiltak, som omfatter universelle, selektive og indikerte intervensjoner, men hvordan treffer tiltakene unge mennesker? For å besvare dette spørsmålet, gjennomførte vi 1) en systematisk gjennomgang og metaanalyse av nesten 100 studier som undersøkte hele spekteret av selvmordsforebyggende intervensjoner rettet mot unge, og 2) dialog med unge mennesker fra hele Australia. Dette resulterte i et program som ble utviklet spesielt av og for unge mennesker, som aktive samarbeidspartnere i forskningen. I denne artikkelen beskriver vi noen av hullene i dagens forsknings- og forebyggingstiltak som er rettet mot unge, og diskuterer noen av utfordringene og mulighetene som ligger i å inkludere unge mennesker som aktive partnere i selvmordsforskning.

THE RATES OF YOUTH SUICIDE are increasing internationally. Whilst more young men take their own lives, some of the greatest increases appear to be among young women (Stefanac et al., 2019). Rates of suicide attempt, self-harm, depression and anxiety also appear to be rising in young people (Robinson et al., 2016). The reasons for this are complex and multiple: increasing societal pressures, including access to education, employment and financial independence (Sweeting et al., 2010), limitations of the health care system (Robinson et al., 2016), and, some would argue, the increasing presence of social media in young people's lives (Orben \& Przybylski, 2019). Whatever the reasons, our challenge is to find solutions.

Frameworks for suicide prevention activities exist and can be applied across a range of settings. Probably the most commonly applied framework was originally developed by Mrazek and Haggerty (Mrazek \& Haggerty, 1994) to describe mental health interventions, and was later applied to suicide prevention by Silverman and Maris (Silverman \& Maris, 1995). This classifies interventions as universal, selective or indicated, on the basis of how their target groups are defined.

Universal interventions target whole populations with the aim of reducing risk factors or enhancing protective factors across an entire 
population or community, for example interventions aimed at improving media reporting of suicide. Selective interventions target subgroups who are displaying signs or symptoms which could place them at greater risk in the future and typically include training and education programs (frequently known as 'gatekeeper' programs) for people who come in to contact with high-risk individuals. Finally, indicated interventions target people who are already displaying suicidal behaviour, most commonly face-to-face treatment delivered in clinical settings. But how do these types of intervention apply to youth suicide prevention and do they work?

In order to answer these questions, we conducted two activities: a systematic review and meta-analysis of almost 100 studies that examined the full spectrum of youth suicide interventions tested across community, educational/workplace and clinical settings (Robinson et al., 2018a), and a consultation with young people (Robinson et al., 2016).

Results from the systematic review indicated that the number of intervention studies has increased over time and many of the interventions showed promise, in particular large-scale studies testing brief contact/ postcard interventions in emergency departments, and multi-modal interventions comprising universal, selective and indicated components in school settings.

However, despite these promising findings, significant gaps remain. Studies were of limited quality - often underpowered due to difficulties recruiting and retaining adequate sample sizes. We also found very few studies that tested digital interventions, despite their popularity among young people, increasing evidence supporting their acceptability among young people at risk of suicide (Witt et al., 2017), and their efficacy in the treatment of depression and anxiety (Välimäki et al., 2017). And critically, the majority of interventions tested were not designed specifically for young people, with only a small minority reporting having young people actively involved in the work itself.

This presents a clear disconnect between the research being conducted and the people it is trying to help and begs the question: could our efforts to reduce youth suicide be enhanced by greater involvement of young people themselves? When we have asked young people this, the response was a resounding "yes" (Robinson et al., 2016).

The importance of consumer participation in health research, often termed public patient involvement, is becoming increasingly recognised around the world (National Health and Medical Research Council, 2016). Benefits of such partnerships include: increased relevance (i.e. ensuring that the interventions being tested are appropriate and youth-friendly), improved stakeholder engagement (e.g. youth-friendly methodologies leading to improved rates of recruitment and retention), improved long-term outcomes (e.g. implementation and 
scalability of interventions), and ultimately, participant empowerment and social engagement (i.e. giving young people the agency to help shape solutions to their own problems) (Darnay et al., 2019; Faithfull et al., 2019).

With these benefits in mind, what would suicide prevention research look like moving forward?

According to the young people we asked we would be testing different interventions that better reflect the ways in which young interact with each other and the health system. In particular, young people want suicide to be spoken about openly, yet safely, in the media (including social media), and also in educational settings (both schools and universities); they want interventions that help to empower them to help each other, as opposed to those that only focus on upskilling adults or professional 'gatekeepers', such as teachers; and they want blended models of healthcare that integrate digital and face-to-face solutions (Robinson et al., 2016). So, if we return to our framework, the overarching model still applies but some of the interventions may

\section{However, the question remains as to whether the real solutions lie not only with individual researchers, but also with those agencies who identify the ways in which research priorities and funding are determined.}

look different for young people. For example, at Orygen we are testing a model of youth suicide prevention that has been co-developed with young people. In this model, at the universal level we have developed, and are testing, guidelines combined with a social media campaign that together aim to help young people talk safely about suicide on social media (Robinson et al., 2018b), at the selective level we have piloted, and are now testing at scale, educational workshops to upskill young people to identify and support friends who may be at risk of suicide (Bailey et al., 2017), and at the indicated level we are testing two online interventions for young people in both clinical and educational settings (Bailey et al., 2020; Hetrick et al., 2017).

However, simply testing youth-friendly interventions is not enough. Young people must also be active and ongoing partners in the research with clear roles to play in engaging participants, intervention delivery, and interpreting the results, if we are to improve recruitment, retention and, crucially, implementation.

Naturally barriers to this exist, including availability of resources. Indeed, for genuine participation to occur, young people need to be involved in all levels of the research process, from the beginning, when the research question is identified and the study designed, through to interpretation and dissemination of the findings. Young people also need to be supported properly. However, this can be both time-consuming and costly. Additional support and training for research staff have been proposed as important enablers to youth partnerships in research, and resources do exist to support these endeavors (Orygen, 2016). However, the question remains as to whether the real solutions lie not only with individual researchers, but also with those agencies who identify the ways in which research priorities and funding are determined.

One might also imagine additional challenges in the area of suicide research specifically, not least because of the sensitive nature of the subject itself. Whilst a growing body of literature tells us that it is safe to include young people as active participants in suicide research (Deeley \& Love, 2010), to the best of our knowledge no studies have tested the impact of including young people as partners in suicide research and no best practice guidelines exist. Further, would all this mean increased participation rates hence better powered studies? And would more youth-friendly interventions lead to better implementation and scalability of effective interventions?

To date, the answers to these questions remain unknown. However, despite these barriers and uncertainties, the increasing rates of youth suicide mean that we urgently need new approaches to suicide prevention research, and one obvious step would be to include young people as active partners in the work that we do. While this may present challenges, the opportunities and potential long-term outcomes are too great to be ignored.

\section{REFERENCES}

Bailey, E., Alvarez-Jimenez, M., Robinson, I., D’Alfonso, S., Nedelikovic, M., Davey, C. G., ... Rice, S. M. (2020). An Enhanced Social Networking Intervention for Young People with Active Suicidal Ideation: Safety, Feasibility and Acceptability Outcomes. International Journal of Environmental Research and Public Health, 17(7), 2435.

Bailey, E., Spittal, M., Pirkis, I., Gould, M., \& Robinson, I. (2017). Universal Suicide Prevention in Young People: An Evaluation of the safeTALK Program in Australian High Schools. Crisis: The Journal of Crisis Intervention and Suicide Prevention, 38(5), 300-308.

Darnay, K., Hawke, L. D., Chaim, G., Henderson, I., \& The INNOVATE Research Team. (2019). INNOVATE Research: Youth Engagement Guidebook for Researchers. Toronto: The Margaret and Wallace McCain Centre for Child Youth \& Family Mental Health.

Deeley, S. T. \& Love, A. W. (2010). Does Asking Adolescents About Suicidal Ideation Induce Negative Mood State? Violence and Victims, 25(5), 677-688.

Faithfull, S., Brophy, L., Pennell, K., \& Simmons, M. (2019). Barriers and enablers to meaningful youth participation in mental health research: Qualitative interviews with youth mental health researchers. Journal of Mental Health, 28(1), 56-63.

Hetrick, S., Yuen, H. P., Bailey, E., Cox, G. R., Templer, K., Rice, S. M., . . . Robinson, I. (2017). Internet-based cognitive behavioural therapy for young people with suicide-related behaviour (Reframe-IT): A randomised controlled trial. Evidence-Based Mental Health, 20(3), 76-82. 
Mrazek, P., \& Haggerty, R. I. (1994). Reducing risks for mental disorders: Frontiers for preventive intervention research. Washington D.C.: National Academy Press.

National Health and Medical Research Council. (2016). Statement on Consumer and Community Involvement in Health and Medical Research. Canberra.

Orben, A., \& Przybylski, A. K. (2019). The association between adolescent well-being and digital technology use. Nature Human Behaviour, 3(2), 173-182.

Orygen (2016). Youth partnerships in research toolkit. Melbourne: Orygen, The National Centre of Excellence in Youth Mental Health.

Robinson, I., Bailey, E., Browne, V., Cox, G. R., \& Hooper, C. (2016). Raising the bar for youth suicide prevention. Melbourne: Orygen, The National Cantre of Excellence in Youth Mental Health.

Robinson, I., Bailey, E., Witt, K., Stefanac, N., Milner, A., Currier, D., . . Hetrick, S. (2018a). What Works in Youth Suicide Prevention? A Systematic Review and Meta-Analysis. EClinicalMedicine, 4(5), 52-91.

Robinson, I., Hill, T. N., Thorn, P., Battersby, R., Teh, Z., Reavley, N. I., ... Skehan, I. (2018b). The \#chatsafe project. Developing guidelines to help young people communicate safely about suicide on social media: A Delphi study. Plos One, 13(11), e0206584.

Silverman, M. M., \& Maris, R. W. (1995). The Prevention of Suicidal Behaviors: An Overview. Suicide and Life-Threatening Behavior, 25(1), 10-21.

Stefanac, N., Hetrick, S., Hulbert, C., Spittal, M., Witt, K., \& Robinson, I. (2019). Are young female suicides increasing? A comparison of sex-specific rates and characteristics of youth suicides in Australia over 2004-2014. BMC Public Health, 19(1), 1389.

Sweeting, H., West, P., Young, R., \& Der, G. (2010). Can we explain increases in young people's psychological distress over time? Social Science and Medicine, 71(10), 1819-1830.

Välimäki, M., Anttila, K., Anttila, M., \& Lahti, M. (2017). Web-Based Interventions Supporting Adolescents and Young People With Depressive Symptoms: Systematic Review and Meta-Analysis. JMIR mHealth and uHealth, 5(12), e180.

Witt, K. G., Spittal, M. I., Carter, G., Pirkis, I., Hetrick, S., Currier, D., , . Milner, A. (2017). Effectiveness of online and mobile telephone applications ('apps') for the self-management of suicidal ideation and self-harm: A systematic review and meta-analysis. BMC Psychiatry, 17(1), 297.

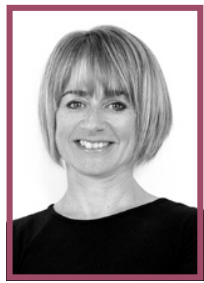

JO ROBINSON is an Associate Professor and head of Suicide Prevention. She is funded by a National Health and Medical Research Council Career Development Fellowship (ID: 1142348).

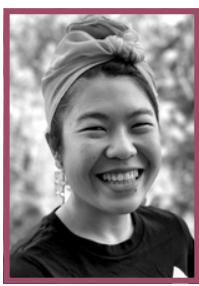

ZOE TEH was formerly a Youth Advisor to the \#chatsafe project and is now a Research Assistant.

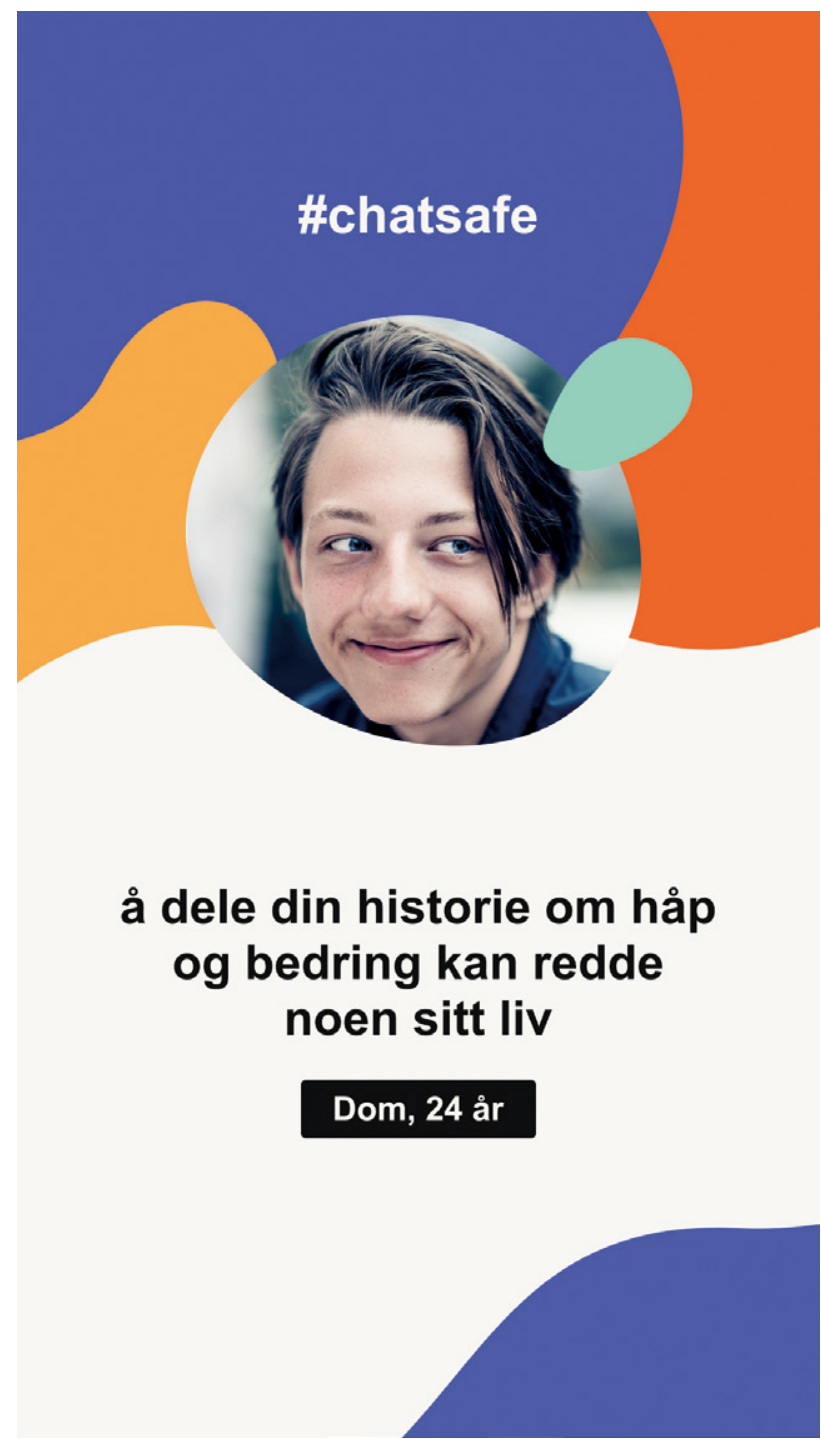

The \#chatsafe website: https://www.orygen.org.au/chatsafe 